\title{
Penggunaan Model Pembelajaran Flipped Classroom untuk Pembelajaran Daring Sosiologi di Masa Pandemi Covid-19 Kelas XII. IPS SMA Negeri 1 Juwana Kab. Pati tahun 2020
}

\author{
Suharno ${ }^{\text {a, } 1}$ \\ a SMA Negeri 1 Juwana, suharsos@gmail.com
}

\begin{tabular}{|c|c|}
\hline & ABSTRAK \\
\hline $\begin{array}{l}\text { Kata kunci: } \\
\text { flipped } \\
\text { classroom } \\
\text { pembelajaran } \\
\text { daring } \\
\text { kompetensi } \\
\text { ketrampilan } \\
\text { berpikir kritis } \\
\text { kreatif } \\
\text { kolaborasi } \\
\text { komunikasi }\end{array}$ & 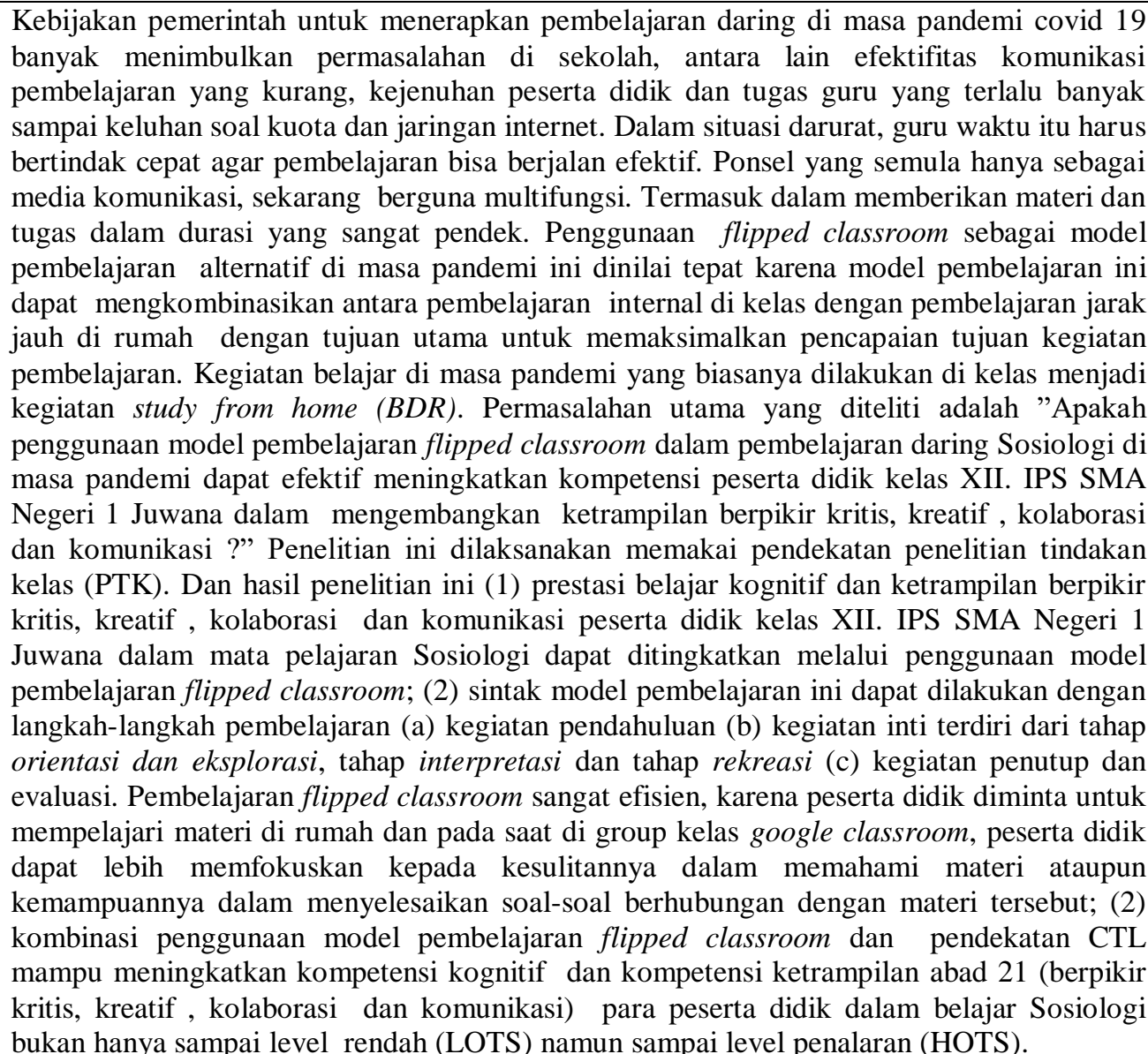 \\
\hline
\end{tabular}

\begin{tabular}{|c|c|}
\hline & ABSTRACT \\
\hline $\begin{array}{l}\text { Keyword: } \\
\text { flipped classroom } \\
\text { online learning } \\
\text { cognitive } \\
\text { competence } \\
\text { critical thinking } \\
\text { creative } \\
\text { collaboration } \\
\text { communication } \\
\text { skills }\end{array}$ & $\begin{array}{l}\text { Government policies to implement online learning during the Covid } 19 \text { pandemic caused } \\
\text { many problems in schools, including the lack of effectiveness of learning communication, } \\
\text { saturation of students and not only too many teacher assignments but also the complaints } \\
\text { about quotas and internet networks. In an emergency situation, the teacher at that time had } \\
\text { to act quickly so that learning could be effective. Cell phone that was originally only as a } \\
\text { medium of communication, is now multi-functional. Included in providing material and } \\
\text { assignments of very short duration. The use of flipped classrooms as an alternative learning } \\
\text { model during this pandemic is considered appropriate because this learning model can } \\
\text { combine internal learning in the classroom with distance learning at home with the main } \\
\text { objective of maximizing the achievement of the objectives of learning activities. Learning } \\
\text { activities during a pandemic that are usually carried out in class become learning activities }\end{array}$ \\
\hline
\end{tabular}


from home (BDR). The main problem studied was "Whether the use of the flipped classroom learning model in sociology online learning during the pandemic can effectively improve the competence of IPS students grade XII SMA Negeri 1 Juwana in developing critical thinking, creative, collaboration and communication skills? " This research was conducted using a classroom action research (PTK) approach. And the results of this study (1) cognitive learning achievement and critical thinking skills, creative, collaboration and communication of IPS students grade XII SMA Negeri 1 Juwana in Sociology subject can be improved through the use of flipped classroom learning model; (2) the syntax of this learning model can be carried out by learning steps (a) preliminary activities (b) core activities consisting of the orientation and exploration stage, the interpretation stage and the recreation stage (c) the closing and evaluation activities. Flipped classroom learning is very efficient, because students are asked to study material at home and in the google classroom group, students can focus more on their difficulties in understanding the material or their ability to solve problems related to the material; (2) the combination of using the flipped classroom learning model and the CTL approach is able to improve the cognitive competence and skills competence of the 21 st century (critical thinking, creative thinking, collaboration and communication) of students in learning sociology not only to the low level (LOTS) but also to the level of reasoning ( HOTS).

Copyright $@$ 2018Tadris IPS Institut Agama Islam Negeri Kudus. All RightReserved

\section{Pendahuluan}

Menurut UNESCO, lebih dari $91 \%$ populasi siswa dunia telah dipengaruhi oleh penutupan sekolah karena pandemi COVID19. Dalam rangka mencegah penyebaran dan penularan virus Covid-19 di lingkungan satuan pendidikan, Kemendikbud telah mengambil kebijakan untuk mengubah kegiatan belajar mengajar dialihkan melalui penyelenggaraan pembelajaran jarak jauh (PJJ) study from home, sesuai dengan Surat Edaran Sekretaris Jenderal Kementerian Pendidikan dan Kebudayaan Nomor 15 Tahun 2020 tentang Pedoman Penyelenggaraan Belajar dari Rumah dalam Masa Darurat Penyebaran Coronavirus Disease (Covid-19).

Belajar dari rumah selama darurat penyebaran Corona Virus Disease (Covid-19) dilaksanakan dengan tetap memperhatikan protokol penanganan Covid-19. Belajar dari rumah melalui pembelajaran jarak jauh daring dan/atau luring . Kegiatan study from home (BDR) dilaksanakan untuk memberikan pengalaman belajar yang bermakna bagi peserta didik, tanpa terbebani tuntutan menuntaskan seluruh capaian kurikulum. Pembelajaran daring (dalam jaringan) atau sebutan lainnya adalah pembelajaran online kini dijalankan sesuai kebijakan lembaga pendidikan masing-masing. Akibatnya, proses belajar daring ini terlaksana sangat variatif dengan gaya masing-masing sekolah.
Namun, hal yang paling mendasar sekaligus menjadi momok mematikan yang tidak terpikirkan oleh banyak pihak penyelenggara pendidikan sesungguhnya bukanlah dari pihak peserta didik melainkan dari pihak pendidik (guru). Seberapa siapkah guru-guru kita menyediakan pembelajaran online yang benar-benar efektif, on target, dan efisien?

Berdasarkan hasil pengamatan terhadap proses pembelajaran daring mulai pertengahan Maret 2020 sampai awal Juni 2020 yang dilakukan guru dan hasil diskusi dengan guru beberapa guru sosiologi bahwa terjadi penurunan prestasi belajar peserta didik, target kompetensi yang diharapkan disebabkan penerapan metode pembelajaran daring yang monoton dilakukan memiliki fenomena bahwa proses belajar yang terjadi secara aktif hanya peserta didik yang termasuk kelompok atas $\left(_{ \pm} 10 \%\right)$ mulai dari kegiatan persiapan pembelajaran daring, kegiatan mandiri mengerjakan tugas, pelaksanaan diskusi online dengan zoom dan termasuk pelaporan dan pengumpulan hasil tugas yang diberikan guru dalam PJJ. Sementara sebagian besar peserta didik yang kelompok menegah ke bawah $( \pm 90 \%)$ punya kecenderungan kurang aktif, mereka sering terlambat ikut daring, kegiatan mandiri penugasan untuk belajar awal masih minim bahkan ada sebagian peserta didik titip nama dalam pengumpulan tugas kelompok. Ini terlihat mencolok dalam 
PJJ bahwa peserta didik kelompok atas nampak mendominasi dan lebih aktif dalam pembelajaran daring dan diskusi serta presentasi hasil tugas. Hal ini disebabkan guru belum optimal dalam menempatkan posisi dan fungsi guru sebagai fasilitator (menjembatani pembelajaran), dinamisator (penggerak perubahan) dan pemberi dorongan (motivasi) proses pembelajaran daring maka upaya peningkatan kompetensi kogintif dan ketrampilan peserta didik abad 21 ( berpikir kreatif, komunikatif, kolaboratif dan kreatif) belum bisa tercapai secara maksimal. Data dari guru sosiologi kelas XII. IPS di SMA Negeri 1 Juwana pada bulan Maret 2020 s.d Juni 2020 menunjukkan hasil penilaian pada aspek keterampilan berpikir kritis, berkolaborasi, berkomunikasi dan kreatifitas pada pembelajaran daring tahap awal nilai rataratanya 68,78 termasuk kategori rendah.

Dalam situasi darurat, guru waktu itu harus bertindak cepat untuk mengatasi permasalahan tersebut, agar pembelajaran bisa berjalan efektif. Untuk menyiasati permasalahan di atas, pada tahun pelajaran baru 2020/ 2021, peneliti sebagai guru mencoba menggunakan alternatif model pembelajaran flipped classroom atau pembelajaran terbalik dalam pelaksanaan pembelajaran daring mata pelajaran Sosiologi kelas XII. IPS di SMA Negeri 1 Juwana Kab. Pati.

\section{Medode}

Penelitian ini menggunakan jenis penelitian tindakan kelas (PTK) atau Classroom Action Research (CAR), yaitu jenis penelitian tindakan yang berbasis kelas daring. Tujuan penelitian ini bermaksud untuk meningkatan proses dan hasil pembelajaran daring. Dan penelitian dilakukan menggunakan 3 siklus, dan setiap siklus terdiri atas empat kegiatan yaitu perencanaan, tindakan, pengamatan, dan refleksi. Dengan menggunakan pendekatan partisipatori kolaboratif setiap siklus penelitian ini dilakukan untuk melakukan perubahan konstruktif secara sistematik, lewat kerjasama antara peneliti dengan guru-guru SMA (anggota peneliti) agar terjadi perubahan positif dalam melakukan pendekatan pembelajaran daring terutama dalam meningkatkan prestasi belajar atau kompetensi peserta didik SMA Negeri 1 Juwana dalam mata pelajaran Sosiologi. Subyek penelitian ini adalah kelas XII. IPS.5 SMA Negeri 1 Juwana Kab. Pati yang berjumlah 36 orang peserta didik terdiri dari 14 laki-laki dan 22 perempuan dan 3 guru mata pelajaran sosiologi yang melaksanakan pembelajaran di kelas tersebut.

Metode pengumpulan data yang digunakan dalam penelitian ini yaitu metode pengamatan (observasi), metode tes hasil belajar, dan metode dokumentasi. Analisis data tentang hasil belajar peserta didik digunakan dengan penilaian acuan patokan (PAP). Analisis data hasil sebelum dan sesudah perlakuan/treatment digunakan rumus mean atau pencarian nilai rata-rata. Data yang tidak bisa dianalisis dengan rumus statistik akan dinarasikan kemudian diberi argumen secara diskripsi.

\section{Hasil Pembahasan}

Dari hasil wawancara dengan para guru sosiologi SMA Negeri 1 Juwana Kab. Pati tentang evaluasi pelaksanaan pembelajaran daring di bulan pertengahan Maret sampai April 2020, diperoleh data bahwa guru telah melakukan berbagai upaya pembelajaran daring dengan memanfaatkan aplikasi WA Group dan google classroom yang diharapkan mampu menuntaskan kompetensi dasar di akhir semester. Namun masih banyak kendala dan hambatan dialami guru dan peserta didik dalam pelaksanaan pembelajaran daring, antara lain partisipasi dan keaktifan peserta didik dalam mengikuti pembelajaran daring belum maksimal. Salah satu model pembelajaran daring yang mereka gunakan dan dianggap baik adalah mengimplementasikan pendekatan cara belajar siswa aktif (CBSA) dengan metode diskusi dan penugasan secara daring. Namun 
berdasarkan hasil wawancara dan diskusi pada forum MGMP Sekolah khusus guru Sosiologi SMA Negeri 1 Juwana tersebut diperoleh data dan informasi bahwa melalui metode diskusi dan penugasan daring yang dilakukan dalam pembelajaran daring menunjukkan hasil bahwa para peserta didik kelompok atas (yang pandai) sekitar $\pm 10 \%$ sangat aktif mendominasi pembelajaran sedangkan kelompok menengah (midle) ke bawah, termasuk kelompok yang rendah (lower group students) sangat pasif, dan hasil pembelajaran sangat kurang memuaskan. Hal tersebut menunjukkan kesenjangan yang semakin lebar prestasi hasil belajar (dilihat dari nilai hasil ulangan) yang diperoleh antara peserta didik kelompok atas yang tergolong upper group students dengan para peserta didik kelompok menengah ke bawah yang tergolong berkemampuan relatif rendah. Data lain juga menunjukkan bahwa kemampuan dan ketrampilan untuk berpikir kritis, kreatif, kolaborasi dan komunikatif dalam pembelajaran daring untuk peserta didik kelompok atas yang tergolong upper group students nampak semakin berkembang dan cenderung mendominasi, sementara yang midle group students ke bawah nampak belum ada peningkatan dan bahkan cenderung turun serta berprestasi belajar rendah. Jadi target ketuntasan belajar tercapai pada kelompok yang tergolong kelompok atas saja yang relatif mencapai target kompetensi yang diharapkan, sementara kelompok yang lain belum mencapai ketuntasan yang diharapkan.

Hal ini nampak ketika dihadapkan pada soal-soal level penalaran (HOTS) dan tugas-tugas penguasaan pengetahuan tingkat C3-C6 (aplikasi, analisa, sintesa dan evaluasi) sangat mengalami kesulitan. Peserta didik yang temasuk kelompok atas punya keterampilan berpikir kritis, kreatifitas, kolaboratif dan komunikatifnya cukup baik. Rendahnya sebagian besar prestasi belajar daring dan keterampilan $4 \mathrm{C}$ yang diperoleh peserta didik atau target kompetensi yang diharapkan guru disebabkan penerapan metode penugasan dalam pembelajaran daring memiliki fenomena bahwa proses belajar yang terjadi secara aktif hanya peserta didik yang termasuk kelompok atas mulai dari kegiatan merencanakan, melaksanakan (pembelajaran daring) dan melaporkan hasil tugas yang diberikan oleh guru. Sementara peserta didik yang temasuk kelompok menengah ke bawah, keterampilan berpikir kritis, kreatifitas, kolaboratif dan komunikatifnya kurang. Mereka dalam mengikuti pembelajaran daring cenderung pasif dan hanya sebagai pelengkap dan titip nama dalam laporan tugas daring kelompok. Sehingga proses pembelajaran daring cenderung didominasi dan dimonopoli peserta didik yang tergolong kelompok atas yang jumlahnya minim (3-4 anak) dalam penugasan dan diskusi online.

Berdasarkan skenario yang disepakati bersama, peneliti (guru/peneliti anggota) melakukan pembelajaran daring sementara peneliti melakukan pengamatan. Setelah evaluasi formatif dilaksanakan, peneliti bersama praktisi/anggota peneliti melakukan refleksi atas kegiatan dan hasil pembelajaran daring yang telah dilakukan. Adapun rata-rata hasil evaluasi pembelajaran daring ( hasil penilaian harian /formatif hasil tes) pada setiap siklus dapat dilihat pada tabel 2 dan tabel 3 . 
Tabel 2. Hasil Tes Formatif Siklus I, II, dan III

\begin{tabular}{|c|c|c|c|c|c|c|c|c|}
\hline \multirow[b]{2}{*}{ No. } & \multirow{2}{*}{$\begin{array}{c}\text { Interval } \\
\text { Nilai }\end{array}$} & \multicolumn{2}{|c|}{ Siklus I } & \multicolumn{2}{|c|}{ Siklus I } & \multicolumn{2}{|c|}{ Siklus I } & \multirow[b]{2}{*}{ Ket. } \\
\hline & & $\begin{array}{c}\text { Jumlah } \\
\text { Siswa }\end{array}$ & $\%$ & $\begin{array}{c}\text { Jumlah } \\
\text { Siswa }\end{array}$ & $\%$ & $\begin{array}{c}\text { Jumlah } \\
\text { Siswa }\end{array}$ & $\%$ & \\
\hline 1 & $96-100$ & - & - & 3 & $8,33 \%$ & 2 & $5,55 \%$ & Tuntas \\
\hline 2 & $91-95$ & - & - & 9 & $25,00 \%$ & 5 & $13,89 \%$ & Tuntas \\
\hline 3 & $86-90$ & 2 & $5,55 \%$ & 6 & $16,67 \%$ & 13 & $36,11 \%$ & Tuntas \\
\hline 4 & $81-85$ & 5 & $13,89 \%$ & 7 & $19,44 \%$ & 3 & $8,33 \%$ & Tuntas \\
\hline 5 & $76-80$ & 14 & $38,89 \%$ & 5 & $13,89 \%$ & 10 & $27,78 \%$ & Tuntas \\
\hline 6 & $71-75$ & 7 & $19,44 \%$ & 5 & $13,89 \%$ & 2 & $5,55 \%$ & Belum tuntas \\
\hline 7 & $66-70$ & 4 & $11,11 \%$ & - & - & 1 & $2,78 \%$ & Belum tuntas \\
\hline 8 & $61-65$ & 2 & $5,55 \%$ & - & - & - & - & Belum tuntas \\
\hline 9 & $56-60$ & 1 & $2,78 \%$ & - & - & - & - & Belum tuntas \\
\hline 10 & $51-55$ & - & - & 1 & $2,78 \%$ & - & - & Belum tuntas \\
\hline 11 & $46-50$ & - & - & - & - & - & - & Belum tuntas \\
\hline 12 & $41-45$ & - & - & - & - & - & - & Belum tuntas \\
\hline 13 & $36-40$ & - & - & - & - & - & - & Belum tuntas \\
\hline 14 & $31-35$ & 1 & $2,78 \%$ & - & - & - & - & Belum tuntas \\
\hline 15 & $<31$ & - & - & & - & - & - & Belum tuntas \\
\hline & umlah & 36 & - & 36 & 100 & 36 & 100 & \\
\hline Nila & $\begin{array}{l}\text { Rata-rata } \\
\text { Kelas }\end{array}$ & \multicolumn{2}{|c|}{74,50} & \multicolumn{2}{|c|}{79,83} & \multicolumn{2}{|c|}{84,61} & \\
\hline & $\begin{array}{l}\text { 'ingkat } \\
\text { tuntasan }\end{array}$ & \multicolumn{2}{|c|}{$52,77 \%$} & \multicolumn{2}{|c|}{$69,44 \%$} & \multicolumn{2}{|c|}{$91,67 \%$} & \\
\hline
\end{tabular}

Tabel 3. Lembar Penilaian Keterampilan 4 C Peserta Didik Dalam Pembelajaran Daring Sosiologi Siklus I, II. III

\begin{tabular}{|c|c|c|c|c|c|c|c|c|c|c|c|c|}
\hline \multirow{3}{*}{ No } & \multicolumn{3}{|c|}{$\begin{array}{c}\text { Ketrampilan } \\
\text { berfikir kritis }\end{array}$} & \multicolumn{3}{|c|}{$\begin{array}{l}\text { Ketrampilan } \\
\text { berkolaborasi }\end{array}$} & \multicolumn{3}{|c|}{$\begin{array}{c}\text { Ketrampilan } \\
\text { berkomunikasi }\end{array}$} & \multicolumn{3}{|c|}{$\begin{array}{c}\text { Ketrampilan } \\
\text { kreatifitas }\end{array}$} \\
\hline & \multicolumn{3}{|c|}{$\overline{\mathbf{A}}$} & \multicolumn{3}{|c|}{$\overline{\mathbf{B}}$} & \multicolumn{3}{|c|}{$\bar{C}$} & \multicolumn{3}{|c|}{ D } \\
\hline & SI & SII & SIII & SI & SII & SIII & SI & SII & SIII & SI & SII & $\overline{\text { SIII }}$ \\
\hline S1 & 21 & 23 & 23 & 25 & 25 & 25 & 23 & 23 & 23 & 22 & 22 & 22 \\
\hline S2 & 15 & 17 & 20 & 10 & 15 & 19 & 18 & 19 & 20 & 15 & 18 & 19 \\
\hline S3 & 15 & 15 & 18 & 10 & 15 & 20 & 15 & 15 & 17 & 10 & 15 & 18 \\
\hline S4 & 20 & 20 & 20 & 15 & 20 & 22 & 20 & 20 & 20 & 15 & 17 & 21 \\
\hline S5 & 22 & 22 & 22 & 20 & 21 & 23 & 20 & 20 & 22 & 15 & 20 & 22 \\
\hline S6 & 20 & 21 & 22 & 23 & 23 & 23 & 25 & 25 & 25 & 20 & 20 & 21 \\
\hline S7 & 18 & 18 & 20 & 17 & 20 & 20 & 20 & 20 & 20 & 15 & 15 & 18 \\
\hline S8 & 15 & 17 & 20 & 16 & 16 & 20 & 18 & 18 & 19 & 17 & 18 & 20 \\
\hline S9 & 17 & 18 & 21 & 22 & 22 & 22 & 18 & 20 & 21 & 24 & 24 & 24 \\
\hline S10 & 20 & 21 & 22 & 20 & 20 & 19 & 20 & 20 & 20 & 18 & 18 & 22 \\
\hline S11 & 18 & 20 & 21 & 20 & 20 & 22 & 20 & 20 & 20 & 17 & 18 & 19 \\
\hline S12 & 15 & 15 & 20 & 10 & 15 & 20 & 18 & 18 & 18 & 15 & 15 & 17 \\
\hline S13 & 17 & 17 & 17 & 15 & 18 & 20 & 18 & 18 & 20 & 16 & 16 & 16 \\
\hline S14 & 18 & 18 & 20 & 12 & 19 & 21 & 18 & 18 & 18 & 15 & 15 & 22 \\
\hline S15 & 23 & 23 & 23 & 21 & 21 & 21 & 21 & 21 & 21 & 16 & 21 & 22 \\
\hline S16 & 15 & 20 & 20 & 17 & 20 & 20 & 18 & 18 & 21 & 15 & 15 & 21 \\
\hline S17 & 16 & 16 & 21 & 15 & 17 & 19 & 18 & 18 & 18 & 17 & 18 & 20 \\
\hline S18 & 18 & 18 & 19 & 12 & 20 & 20 & 18 & 18 & 20 & 16 & 19 & 19 \\
\hline S19 & 20 & 20 & 20 & 21 & 22 & 22 & 22 & 22 & 22 & 19 & 19 & 21 \\
\hline S20 & 22 & 22 & 22 & 21 & 21 & 21 & 19 & 19 & 19 & 16 & 19 & 21 \\
\hline S21 & 12 & 17 & 18 & 13 & 15 & 20 & 17 & 17 & 17 & 16 & 20 & 20 \\
\hline S22 & 24 & 24 & 24 & 23 & 23 & 23 & 21 & 23 & 23 & 22 & 22 & 23 \\
\hline S23 & 18 & 18 & 19 & 17 & 21 & 21 & 18 & 18 & 18 & 18 & 18 & 21 \\
\hline S24 & 20 & 20 & 20 & 19 & 21 & 21 & 20 & 20 & 20 & 21 & 21 & 21 \\
\hline S25 & 19 & 19 & 21 & 18 & 21 & 21 & 21 & 21 & 21 & 20 & 20 & 20 \\
\hline S26 & 18 & 20 & 20 & 18 & 18 & 19 & 20 & 20 & 20 & 20 & 20 & 20 \\
\hline
\end{tabular}




\begin{tabular}{lllllllllllll}
\hline S27 & 19 & 20 & 20 & 21 & 21 & 21 & 18 & 18 & 21 & 15 & 16 & 20 \\
$\mathbf{S 2 8}$ & 17 & 23 & 23 & 19 & 19 & 19 & 18 & 18 & 19 & 17 & 21 & 21 \\
$\mathbf{S 2 9}$ & 20 & 20 & 20 & 21 & 21 & 21 & 18 & 19 & 21 & 16 & 20 & 20 \\
$\mathbf{S 3 0}$ & 24 & 24 & 24 & 22 & 22 & 22 & 19 & 21 & 21 & 21 & 21 & 21 \\
$\mathbf{S 3 1}$ & 22 & 23 & 23 & 21 & 21 & 22 & 24 & 24 & 24 & 21 & 21 & 21 \\
$\mathbf{S 3 2}$ & 19 & 21 & 21 & 18 & 18 & 21 & 18 & 18 & 18 & 17 & 20 & 20 \\
$\mathbf{S 3 3}$ & 18 & 20 & 20 & 16 & 19 & 22 & 17 & 17 & 17 & 18 & 18 & 19 \\
$\mathbf{S 3 4}$ & 20 & 20 & 20 & 15 & 18 & 18 & 18 & 20 & 20 & 20 & 20 & 22 \\
$\mathbf{S 3 5}$ & 21 & 21 & 21 & 17 & 19 & 19 & 18 & 20 & 20 & 16 & 19 & 21 \\
$\mathbf{S 3 6}$ & 19 & 19 & 22 & 15 & 21 & 21 & 18 & 18 & 18 & 15 & 20 & 20 \\
\hline
\end{tabular}

Nilai rata-rata penilaian keterampilan $4 \mathrm{c}$ peserta didik dalam pembelajaran daring sosiologi siklus I, II, dan III yakni sebesar $72,9,77,75$, dan 82,06 . Berdasarkan data yang diperoleh bahwa prestasi belajar sosiologi dan keterampilan berpikir kritis, berkolaborasi, bekomunikasi dan kreatifitas peserta didik kelas XII.IPS.5 SMA Negeri 1 Juwana di masa pandemi Covid-19 dapat ditingkatkan melalui proses pembelajaran daring dengan penggunaan model pembelajaran flipped classroom yang kreatif dan produktif. Berdasarkan hasil refleksi dan evaluasi bersama antara peneliti dan guru ditemukan data sebagai berikut :

Pertama, kreatifitas dan partisipasi peserta didik secara individu dan dalam kerja kelompok akan terbentuk apabila para peserta didik memiliki berbagai pengalaman penggalian sendiri dari berbagai sumber belajar yang telah dikirimkan guru lebih dahulu sebelum pembelajaran daring dan peserta didik temukan dan hayati secara langsung terkait dengan topik yang dibicarakan dalam kerja/diskusi kelompok atau masyarakat belajar. Hal ini dikarenakan dalam pembelajaran daring, peserta didik sebelumnya diberi kesempatan secara mandiri untuk mempelajari materi yang akan diajarkan guru dari materi yang sudah diberikan lebih awal lewat media / aplikasi. Sehingga peserta didik termotivasi untuk diajak berpikir kritis, berkolaborasi dan berkomunikasi dengan temannya dalam pembelajaran daring yang menggunakan model pembelajaran flipped classroom yang kreatif dan produktif.
Kedua, sebagian besar peserta didik yang memiliki berbagai pengalaman menafsirkan (interpretasi) atas belajar mandiri dan keterampilan mengkomunikasikan hasil penggalian sendiri kepada peserta didik lain lewat diskusi online pemecahan masalah sehingga mereka lebih mampu mere-kreasi konsep, contoh dan aplikasi serta menilai hasil re-kreasi yang mereka lakukan. Oleh karena dalam pembelajaran daring ini memberi kesempatan para peserta didik benar-benar melakukan penggalian sendiri secara lebih lama dan serius (sungguh-sungguh) dibawah bimbingan guru secara online. Keterampilan berpikir kritis peserta didik benar-benar ditumbuhkan untuk mampu mere-kreasi konsep, contoh dan aplikasi serta menilai kebenaran hasil re-kreasi yang anak lakukan.

Ketiga, melalui penggunaan model pembelajaran flipped classroom yang kreatif dan produktif dalam pembelajaran daring Sosiologi secara terbimbing dengan bantuan aplikasi google classroom, group WA kelas dan Zoom, hasilnya pelaksanaan diskusi kelompok daring maupun presentasi hasil diskusi kelas daring nampak lebih komunikatif dan hidup, partisipasi peserta didik masingmasing anggota kelompok dalam diskusi meningkat cukup tinggi, peserta didik lebih mudah merekreasi konsep, contoh, aplikasi dan menilai kebenarannya. Penggunaan model pembelajaran flipped classroom yang kreatif dan produktif dalam pembelajaran daring Sosiologi yang dilakukan secara terbimbing para peserta didik juga mampu menilai hasil rekreasi yang mereka lakukan secara secara lebih mudah. Hal ini sesuai dengan kajian 
teorinya bahwa penggunaan model pembelajaran flipped classroom (pembelajaran terbalik) yang kreatif dan produktif sangat relevan untuk pembelajaran daring/ online (PJJ), karena membuat peserta didik lebih mandiri, terampil berkolaborasi, kreatif, komunikatif dan menuntut mereka mempelajari materi pelajaran terlebih dahulu sebelum ada pertemuan di kelas. Peserta didik dituntut untuk berpikir kritis. Model ini juga membuat peserta didik lebih aktif dan kreatif karena dorongan keingintahuan mereka juga lebih tinggi. Model pembelajaran flipped classroom yang kreatif dan produktif juga sejalan dengan perkembangan ilmu pengetahuan dan teknologi Era Industri 4.0. Perubahan model belajar ini tentu membutuhkan pelatihan dan kesiapan guru, tenaga kependidikan, dan peserta didik dalam merancang rencana pelaksanaan pembelajaran dan media pembelajaran yang kompatibel dengan perkembangan teknologi saat ini.

$$
\text { Melalui penggunaan model }
$$
pembelajaran flipped classroom yang kreatif dan produktif yang terintegrasi dengan pendekatan CTL dalam pembelajaran daring prestasi belajar aspek kognitif peserta didik dapat ditingkatkan dari rata-rata hasil belajar kelas berkisar 74,50 menjadi 84,61. Ini berarti ada peningkatan $13,57 \%$ dari hasil siklus I sampai siklus III. Sedangkan untuk peningkatan $12,50 \%$ aspek keterampilan berpikir kritis, berkolaborasi, berkomunikasi dan kreatifitas dari siklus I nilai rata-rata kelas 72,94 naik menjadi 82,06 pada siklus III. Dengan mengimplementasikan model pembelajaran flipped classroom yang kreatif dan produktif, seorang guru bisa merekayasa proses pembelajaran daring atau menciptakan kondisi belajar daring yang mereka lakukan dapat memberdayakan potensi kognitif dan keterampilan $4 \mathrm{C}$ peserta didik meningkat kualitas dan kuantitasnya. Implementasi model pembelajaran flipped classroom yang kreatif dan produktif pada pembelajaran daring lebih diterima peserta didik karena lebih menarik dan menyenangkan, lebih menantang, tidak membosankan dan peserta didik aktif terlibat dalam proses belajar. Penggunaan model pembelajaran flipped classroom yang kreatif dan produktif mendorong peserta didik tidak hanya mendengar informasi, tetapi ia aktif belajar lebih awal karena materi pelajaran diberikan beberapa hari sebelumnya, peserta didik terlibat melihat, mencari dan menemukan informasi lebih leluasa. Selain itu peserta didik juga terlibat secara dalam menyusun informasi menjadi konsep, meningkat ke generalisasi dan teori. Melalui proses ini pencapaian kognitif hasil belajar peserta didik tidak hanya sampai pada level (LOTS) C1 (pengetahuan yang bersifat recall), $\mathrm{C} 2$ (pemahaman) maupun $\mathrm{C} 3$ (aplikasi) namun lebih jauh dari itu. Perkembangan kognitif mereka mampu sampai pada taraf/ level tinggi (HOTS) yaitu C4 (analisis), C5 (sinteses) dan bahkan sampai C6 (evaluasi). Proses-proses itu semua terjadi dalam proses pembelajaran daring yang menggunakan model pembelajaran flipped classroom yang kreatif dan produktif terintegrasi pendekatan CTL. Hal ini disebabkan mulai pra pembelajaran daring, peserta didik sudah diberikan materi pembelajaran baik berupa video pembelajaran atau presentasi power point dan modul pembelajaran sehingga memotivasi peserta didik untuk lebih kreatif belajar mandiri. Dan pada tahap orientasi dan eksplorasi, peserta didik dituntut untuk menggali informasi pengetahuan lebih mendalam dan menganalisa materi melalui beberapa media atau sumber belajar. Setelah itu masuk pada tahap interpretasi dan tahap rekreasi proses pembelajaran daring dengan model pembelajaran flipped classroom terbukti cocok untuk memberdayakan perkembangan kognitif C.5 (sintesis) dan C.6 (evaluasi) buktinya mulai awal pra pembelajaran daring dengan literasi peserta didik mengembangkan C.1 kemampuan dalam mengingat kembali materi yang telah dipelajari, seperti pengetahuan tentang istilah, fakta khusus, konvensi, kecenderungan dan urutan, klasifikasi dan kategori. Kemudian tahap pendahuluan dan 
tahap orientasi \& eksplorasi menuntut perkembangan kognitif C.2 (pemahaman) yaitu kemampuan dalam memahami materi tertentu yang dipelajari dan C.3 (aplikasi) diartikan sebagai kemampuan menerapkan informasi pada situasi nyata, dimana peserta didik mampu menerapkan pemahamannya dengan cara menggunakannya secara nyata. Di jenjang ini, peserta didik dituntut untuk dapat menerapkan konsep dan prinsip yang ia miliki pada situasi baru yang belum pernah diberikan sebelumnya. Dilanjutkan pada sintak berikutnya tahap interpretasi yang mampu mengembangkan C.4 (analisis) kemampuan peserta didik menguraikan suatu materi menjadi komponen-komponen yang lebih jelas. Peserta didik dituntut untuk menafsirkan dengan menganalisis suatu permasalahan. Dan pada tahap re-kreasi mewajibkan peserta didik untuk menggunakan kemampuan C.5 (sintesis) berupa memproduksi komunikasi yang unik, rencana atau kegiatan yang utuh, dan seperangkat hubungan abstrak. Di jenjang ini, peserta didik dituntut menghasilkan hipotesis atau teorinya sendiri dengan memadukan berbagai ilmu dan pengetahuan. Dan C6 (evaluasi) yang diartikan sebagai kemampuan menilai manfaat suatu hal untuk tujuan tertentu berdasarkan kriteria yang jelas. Kegiatan ini berkenaan dengan nilai suatu ide, kreasi, cara atau metode.

Pada proses pembelajaran yang menggunakan model pembelajaran flipped classroom yang kreatif dan produktif terintegrasi pendekatan CTL dan struktur pengetahuan yang diterapkan pada penelitian tindakan kelas ini mampu membuktikan bahwa perkembangan kognitif peserta didik mampu ditingkatkan sampai level tinggi (HOTS) taraf C6 (evaluasi).

Pada penelitian ini skenario pembelajaran daring menggunakan model pembelajaran flipped classroom yang kreatif dan produktif terintegrasi pendekatan CTL dilakukan sebagai berikut:
Kegiatan Pendahuluan: beberapa hari sebelum pembelajaran daring dimulai, guru harus memberikan materi dalam bentuk bahan ajar / video pembelajaran atau ppt (power point) dan modul dengan menggunakan aplikasi google classroom dan group WA kelas untuk dipelajari lebih dulu di rumah sesuai dengan langkah-langkah model pembelajaran flipped classroom, Pada jam pembelajaran daring peserta didik gabung kelas dengan kode yang diberikan guru, pada awal pembelajaran daring, peserta didik berdoa, melakukan presensi online dan guru menyampaikan langkah-langkah pembelajaran daring, tujuan pembelajaran daring yang akan dicapai dan guru menyampaikan secara garis besar materi yang akan dipelajari dengan memberikan gambaran secara singkat tentang materi pokok yang sesuai tujuan pembelajaran.

Tahap orientasi dan eksplorasi: (1) peserta didik diberi tugas secara individual menggali pengertian / konsep dasar materi tersebut dalam referensi lain; (2) peserta didik dibagai ke dalam kelompok dengan masingmasing kelompok beranggotakan 3-4 orang peserta didik; (3) dalam kelompok peserta didik aktif berdiskusi secara daring tentang hasil penggalian pengertian / konsep dasar materi tersebut. Tahap Interpretasi: (1) secara individu, peserta didik mencari contoh-contoh dari konsep dasar materi tersebut, yang dicontohkan dalam buku; (2) dalam kelompoknya peserta didik berdiskusi secara daring tentang hasil pencarian contoh-contoh nyata yang dicontohkan dalam buku; (3) peserta didik memaparkan hasil kerja kelompoknya melalui mengirimkan ke google classroom; (3) peserta didik lain menanggapi hasil kerja tiap-tiap kelompok dengan memberikan komentar di kolom forum di google classroom dan zoom. Tahap Re-kreasi: (1) secara individul, peserta didik mencari contoh-contoh yang mereka lakukan di masyarakat; (2) dalam kelompoknya, peserta didik mendiskusikan secara daring di kelas contoh-contoh yang dibuat oleh masing- 
masing peserta didik; (3) peserta didik secara bersama menyimpulkan mana-mana contohcontoh yang dibuat dipandang benar; (4) peserta didik bersama guru menilai kebenaran contoh-contoh yang disimpulkan berdasarkan konsep dan teori yang dipelajari. Sementara guru memantau dan mengawasi ketika peserta didik belajar (baik secara individu maupun kelompok) dan memberikan bimbingan secara daring ketika mereka mengalami kesulitan dalam mere-kreasi contoh-contoh dan aplikasi serta menilai hasil re-kreasi mereka. Kegiatan penutup dan evaluasi: (1) bersama guru peserta didik menyimpulkan pelajaran; (2) memberi kesempatan peserta didik untuk menanggapi proses pembelajaran yang baru saja dilakukan.

$\begin{array}{ccc}\text { Dari } & \text { rangkaian langkah-langkah } \\ \text { pembelajaran } & \text { daring tersebut sangat }\end{array}$
membantu peserta didik aktif belajar karena sebelumnya sudah diajak untuk membaca (literasi) materi kemudian ada penjelasan umum materi pembelajaran yang akan disampaikan, dan setelah itu para peserta didik disuruh melakukan pengamatan di lapangan (dengan pedoman pengamatan yang telah disediakan oleh guru) secara individual di lingkungan tempat tinggalnya, kemudian peserta didik disuruh mengumpulkan hasil pengamatan ke guru; dan hasil pengamatan di lapangan didiskusikan secara kelompok untuk membentuk konsep dan generalisasi. Dengan bimbingan guru, peserta didik secara berkelompok diajak berdiskusi untuk mengkonstruksi konsep dan generalisasi materi pembelajaran. Pada tahap ini guru mengajak masing-masing kelompok berdiksusi secara daring lebih intensif bukan hanya sampai mengklasifikasi data dan membuat generalisasi namun diharapkan masing-masing kelompok sampai memperoleh label-label yang kokoh atas data yang telah diklasifikasikan. Pada saat peserta didik berdiskusi daring secara berkelompok guru melalui aplikasi google classroom, group WA dan Zoom membantu para peserta didik yang mengalami kesulitan untuk membentuk konsep atas data yang telah diklasifikasikan dengan cara memancing-mancing, memberikan istilah-istilah yang serupa atau bahasa yang sederhana agar mereka memperoleh padanan kata dengan label-labe yang tepat terhadap data-data yang telah diklasifikasikan. Melalui cara ini diharapkan para peserta didik terbentuk insight untuk mampu menemukan istilah-istilah yang tepat dalam memberikan label terhadap data yang telah diklasifikasikan; kemudian masingmasing kelompok mempresentasikan hasil diskusi; setelah itu guru bersama peserta didik menyusun simpulan; dan diakhiri guru melakukan pengamatan, evaluasi (tes) dan sekaligus refleksi.

Skenario pembelajaran daring yang demikian mampu menumbuhkan semangat peserta didik untuk belajar karena mereka secara bersama-sama tidak hanya mendengar informasi tetapi ia secara aktif belajar, melihat dan berbuat langsung atas fakta yang mereka pelajari. Dengan bimbingan guru para peserta didik memproses sendiri fakta ke dalam bentuk klasifikasi menjadi konsep, generalisasi dan teori. Dengan kata lain proses pembelajaran ini tidak hanya mengaktifkan sebagian diri peserta didik yang belajar tetapi mereka belajar secara total atas dirinya yang dilakukan sendiri. Proses didukung oleh teori gestalt yang menyatakan bahwa proses belajar dilakukan secara total oleh yang belajar (peserta didik) akan meningkatkan pemahaman secara utuh. Hal ini disebabkan karena seluruh indra peserta didik sebagai pintu gerbang masuknya dan terbentuknya pengetahuan dalam diri peserta didik bekerja untuk belajar. Selain itu melalui penggunaan model pembelajaran flipped classroom yang kreatif dan produktif terintegrasi pendekatan CTL dalam pembelajaran daring di era pandemi Covid-19 ini peserta didik mengalami proses belajar dari yang kongkret menuju ke abstrak, sehingga memudahkan peserta didik dalam belajar yang sesuai dengan taraf dan proses belajar manusia. Melalui model dan pendekatan ini para peserta 
didik mengalami proses belajar sendiri untuk mengkonstruksi pengetahuannya secara lebih optimal.

$$
\text { Melalui penggunaan model }
$$
pembelajaran flipped classroom yang kreatif dan produktif terintegrasi pendekatan CTL dan struktur pengetahuan dalam pembelajaran daring sangat membantu peserta didik mampu memhami secara nyata antara pengetahuan riil dalam dunia nyata (kehidupan di masyarakat) dengan pengetahuan konseptual yang diperoleh di sekolah dan penerapannya di masyarakat. Dalam konsep ini peserta didik belajar melalui kegiatan mengalami sendiri dalam lingkungan yang alamiah. Mereka belajar mandiri terbimbing dengan mengamati, mengumpulkan fakta, mengkonstruksi sendiri pengetahuan, kemudian memberi makna pada pengetahuan itu. Dalam proses belajar, para peserta didik akan melihat, mengumpulkan fakta, menganalisa dan menyimpulkan serta memikirkan bagaimana penerapannya di bawah bimbingan guru secara daring.

Penggunaan model pembelajaran flipped classroom yang kreatif dan produktif ini pengetahuan yang dikuasai anak bukanlah seperangkap fakta dan konsep yang siap diterima, tetapi sesuatu yang harus dikonstruksi sendiri oleh peserta didik itu sendiri. Dengan cara ini memungkinkan peserta didik memperoleh pengetahuan bukan hanya tahu dan paham dari apa yang diberikan oleh guru tetapi sampai mereka mampu menerapkan, menganalisa, mengorganisir dan mengevaluasi apakah suatu konsep, generalisasi dan teori itu sesuai dengan fakta atau data di lapangan atau tidak. Sehingga aspek keterampilan 4 C (berpikir kritis, berkolaborasi, berkomunikasi dan kreatifitas) juga meningkat. Dengan penggunaan model pembelajaran flipped classroom yang kreatif dan produktif terintegrasi pembelajaran model CTL peserta didik telah mudah mencerna materi dan lama tersimpan dalam memori. Hal ini disebabkan peserta didik belajar mulai dari yang mudah ke yang sulit, dan dari yang kongkret ke yang abstrak.
Hasil analisis positif dalam proses pembelajaran daring ini sesuai dengan fakta dan teori yang mengatakan bahwa hasil belajar peserta didik (the out come of learning) yang berupa perkembangan kemampuan dan ketrampilan peserta didik akan ditentukan oleh hasil interaksi antara kondisi internal belajar (internal condistions of learning) peserta didik yang berupa kondisi dan proses kognitif peserta didik (the larner's insternal states and cognitive processes) dengan kondisi eksternal belajar (external conditiosn of learning) yang berupa stimulus lingkungan (stimuli from the environment). Prestasi belajar rendah menjadi meningkat karena penggunaan model pembelajaran flipped classroom yang kreatif dan produktif terintegrasi pembelajaran model CTL dalam proses pembelajaran daring yang dilakukan guru mampu meningkatkan motivasi, kemauan, daya serap dan tingkat konsentrasi serta keterampilan peserta didik. Ini terjadi karena dalam proses belajar peserta didik memperoleh pengetahuan secara bertahap sebagaimana halnya model struktur pengetahuan itu terbentuk yaitu mulai dari fakta (contoh nyata perubahan sosial), ke konsep perubahan sosial dan akhirnya ke generalisasi dan atau teori yang berupa menyimpulkan dan menganalisis dampak suatu kasus perubahan sosial. Dengan cara ini memungkinkan peserta didik belajar dengan lebih mudah dan bermakna karena ia belajar mulai dari konteks riil yang dilihat dan didengar dilingkungannya atau mulai dari yang kongkret dan secara bertahap menuju ke abstrak, dari sederhana menuju ke yang komplek. Dengan demikian, melalui penggunaan model pembelajaran flipped classroom yang kreatif dan produktif terintegrasi pembelajaran model CTL ini para peserta didik mengalami proses belajar sendiri mulai dari belajar mandiri, melihat atau mendengar fakta, mengumpulkan fakta, menganalisa, mengkonstruksi fakta menjadi konsep dan generalisasi serta teori dan bahkan menilai konsep, generalisasi dan teori itu sesuai dengan faktanya atau tidak. 


\section{Simpulan}

Berdasarkan pembahasan temuan hasil penelitian di atas, dapat disimpulkan sebagai berikut: Pertama, prestasi belajar sosiologi dan keterampilan berpikir kritis, berkolaborasi, bekomunikasi dan kreatifitas peserta didik kelas XII.IPS.5 SMA Negeri 1 Juwana di masa pandemi Covid-19 dapat ditingkatkan melalui proses pembelajaran daring dengan penggunaan model pembelajaran flipped classroom yang kreatif dan produktif. Kedua, integrasi model pembelajaran flipped classroom ini dapat dilakukan dengan langkah-langkah sebagai berikut :

Kegiatan Pendahuluan: beberapa hari sebelum pembelajaran daring dimulai, guru harus memberikan materi dalam bentuk bahan ajar / video pembelajaran atau ppt (power point) dan modul dengan menggunakan aplikasi google classroom dan group WA kelas untuk dipelajari lebih dulu di rumah sesuai dengan langkah-langkah model pembelajaran flipped classroom. awal pembelajaran daring, peserta didik berdoa, melakukan presensi online dan guru menyampaikan langkahlangkah pembelajaran daring, tujuan pembelajaran daring yang akan dicapai dan guru menyampaikan secara garis besar materi yang dipelajari.

Tahap orientasi dan eksplorasi. Peserta didik mengumpulkan informasi dengan berpikir kritis setelah membaca materi dalam bentuk bahan ajar / video pembelajaran atau ppt (power point) dan modul dengan menggunakan aplikasi google classroom yang berkaitan dengan pengertian perubahan sosial dan mencari contoh kasus nyata perubahan sosial . Pada tahap ini mengembangkan ketrampilan critical thinking.

Tahap Interpretasi. Peserta didik dibentuk dalam beberapa kelompok untuk mendiskusikan, mengumpulkan informasi, berkolaborasi, dan saling bertukar informasi. Peserta didik mencari contoh-contoh dari konsep dasar materi tersebut. Pada tahap ini mengembangkan ketrampilan collaboration.

Tahap Re-kreasi. Peserta didik mendiskusikan, mempresentasikan secara daring di kelas maya dan menyimpulkan. Peserta didik mempresentasikan hasil kerja kelompok atau individu secara klasikal, mengemukakan pendapat atas presentasi yang dilakukan kemudian ditanggapi kembali oleh kelompok atau individu yang mempresentasikan. Pada tahap ini mengembangkan ketrampilan communication dan creativity.

Kegiatan penutup dan evaluasi. Peserta didik bersama guru menyimpulkan hasil pelajaran dan memberi kesempatan peserta didik untuk menanggapi proses pembelajaran yang baru saja dilakukan.

Pembelajaran flipped classroom sangat efisien, karena peserta didik diminta untuk mempelajari materi di rumah dan pada saat di group kelas google classroom, peserta didik diajak mencari, melihat, memilih dan mengumpulkan fakta-fakta dalam dunia nyata; mengklasifikasi fakta; dibimbing berdiskusi untuk menyusun konsep dan melabeli data yang telah terklasifikasi, menyusun generalisasi dan teori berdasarkan fakta yang diperoleh sehingga dapat lebih memfokuskan kepada kesulitannya dalam memahami materi ataupun kemampuannya dalam menyelesaikan soal-soal berhubungan dengan materi tersebut.

$$
\text { Ketiga, penggunaan model }
$$
pembelajaran flipped classroom dan pendekatan CTL secara terintegrasi mampu meningkatkan kompetensi kognitif para peserta didik dalam belajar Sosiologi sampai level penalaran (HOTS), analisis, sintesis dan evaluasi atas materi yang dipelajari peserta didik.

\section{Referensi}

Abeysekera, L., \& Dawson, P. 2015. Motivation and cognitive load in theflipped classroom: definition, rationale and a call for research. Higher Education Research \& Development.

Adhitiya, E.N., Prabowo, A. dan Arifuddin, R. $\begin{array}{llr}\text { 2015. Studi } & \text { Komparasi } & \text { Model } \\ \text { Pembelajaran } & \text { Traditional } & \text { Flipped } \\ \text { Classroom dengan Peer Instruction }\end{array}$ 
Flipped terhadap Kemampuan Pemecahan Masalah. Unnes Journal of Mathematics Education 4.

Bergmann, J., dan Sams, A. 2012. Flip Your Classroom: Reach Every Student in Every Class Every Day. USA: Courtney Burkholder.

http://video.kemendikbud.go.id

https://belajar.kemendikbud.go.id

https://perpustakaan.kemendikbud.go.id/jurna l-kemendikbud

Johnson, G.B. 2013. Student Perceptions Of The Flipped Classroom. Columbia: The University Of British Columbia.

Milman, Natalie B. 2012. The Flipped Classroom Strategy What is it and can it best be used?. Jurnal Internasional, Vol.9, Issue 3: The George Washington University.

Muir, T., \& Geiger, V. 2016. The Affordances of Using a Flipped Classroom Approach in the Teaching Of Mathematics: A Case Study of a Grade 10 Mathematics Class. Mathematics Education Research Journal.

Permendikbud RI Nomor 37 tahun 2018 tentang Perubahan Atas Permendikbud No.24 tahun 2016 tentang Kompetensi Inti dan Kompetensi Dasar Pelajaran Kurikulum 2013 pada Pendidikan Dasar dan Pendidikan Menengah.

Redhana, I. Wayan.2019. Mengembangkan Ketrampilan Abad 21 dalam Pembelajaran Kimia. Jurnal Inovasi Pend. Kimia. Vol.13 No.1

Subandowo, M. (2017). Peradaban Dan Produktivitas Dalam Perspektif Bonus Demografi Serta Generasi Y Dan Z. Sosiohumanika: Jurnal Pendidikan Sains Sosial Dan Kemanusiaan, 10(November):191-208.
Surat Edaran Mendikbud Nomor 4 tahun 2020 tentang Belajar dari Rumah melalui Pembelajaran Jarak Jauh

Surat Edaran Sekretaris Jenderal Kementerian Pendidikan dan Kebudayaan Nomor 15 tahun 2020 tentang Pedoman Penyelenggaraan Belajar dari Rumah dalam masa Darurat Penyebaran Covid-19

Utami, Sri. 2017. Pengaruh Model Pembelajaran Flipped Classroom Tipe Peer Instruction Flipped Terhadap Kemampuan Pemecahan Masalah Matematik Siswa. Jakarta: Universitas Islam Negeri Syarif Hidayatullah Jakarta.

Yulietri, F., Mulyoto dan Agung, Leo. 2015. Model Flipped Classroom dan Discovery Learning Pengaruhnya Terhadap Prestasi Belajar Matematika Ditinjau dari Kemandirian Belajar. Jurnal Teknologi Pendidikan Pasca Sarjana UNS, Vol.13, No.2. 